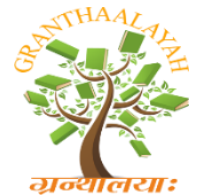

\author{
INTERNATIONAL JOURNAL OF RF
GRANTHAALAYAH \\ A knowledge Repository
}

Management

\title{
IMPACT OF DEMOGRAPHIC FACTORS GENDER AND NUMBER OF YEARS OF ERP POST IMPLEMENTATION OPERATIONS ON USER PRODUCTIVITY: AN EMPIRICAL STUDY IN HIGHER EDUCATION SETTINGS, IN INDIAN CONTEXT
}

\author{
Nirmal Iyengar ${ }^{1}$, Dr. Pushpkant Shakdwipee ${ }^{2}$ \\ ${ }^{1}$ Visiting Faculty, IBS, Mumbai, India \\ ${ }^{2}$ Associate Professor, Pacific University, Udaipur, India
}

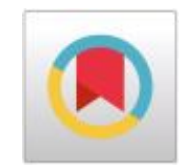

\begin{abstract}
Motivation and Background: The findings from review of extant literature indicated that the actual impact of ERP is generally seen and felt by an organizations during its post implementation stage. It is in this stage that the organizations commence on their journey of using the ERP systems, and start relating to its utility for the activities and processes being carried out by the employees. It is therefore, essential for the organizations to effectively manage the performance of the ERP system in the post implementation stage to deliver expected benefits to the business. Accordingly, it is important to study and understand various influences prevailing upon the ERP system during the post implementations stage and use the knowledge to ensure better managing the deliverables of ERP systems, therein. Evidence from the past studies suggest that the different business settings have varied notable influences on the ERP implementation across phases. The Higher Education Sector in India is growing at a pace, seen never before, and the need to respond to competition pressures, student acquisition, renewed needs of students, and other stake holders, regulatory impositions by the government, globalization. These are few of the many reasons prompting the Higher Education Institutions (HEIs) to consider and implement solutions to help them respond to these changing needs so as to better deliver stakeholder's expectations and satisfaction. Productivity of users in the ERP post implementation stage plays an important role in ensuring performance and success of the ERP systems. Guided by the above observations, this paper, through an empirical study, investigates the influence of gender and the period of ERP operations post its implementation, on the productivity of users, across higher education institutions, in an Indian context.

Method: A factorial design of ANOVA coupled with a descriptive analysis, was used to study the research problem. A variety of journals were explored using appropriate key words extracted in the review of literature, during the initial stage. A study of abstracts of articles in the subsequent reviews, resulted in focusing on a select few studies, whose detailed examination, helped in determining the gaps. Choosing a purposive sampling method, a survey was administered on the target respondents. The survey included 101 respondents from four HEIs, in an Indian context. The hypotheses associated with the research problem were then analysed using the primary data
\end{abstract}


applying the factorial design of ANOVA, to study the influence of individual factors as well as a combination of factors, on the user productivity, during the ERP post implementation stage.

Conclusion: The study revealed that the factors, namely Gender \& Period of ERP operations after implementation, considered individually, and in combination, significantly influenced, the productivity of users during the ERP post implementation stage. A descriptive study further helped to understand and explain the variations in the mean ratings, across factor group.

Keywords: ERP; Post-Implementation Impact; ERP Usage; Individual Impact on Productivity; Combined Impact on Productivity.

Cite This Article: Nirmal Iyengar, and Dr. Pushpkant Shakdwipee. (2019). "IMPACT OF DEMOGRAPHIC FACTORS GENDER AND NUMBER OF YEARS OF ERP POST IMPLEMENTATION OPERATIONS ON USER PRODUCTIVITY: AN EMPIRICAL STUDY IN HIGHER EDUCATION SETTINGS, IN INDIAN CONTEXT." International Journal of Research - Granthaalayah, 7(11), 106-113. 10.29121/granthaalayah.v7.i11.2020.341.

\section{Introduction}

ERP implementation are quite infamous because of its associated peril and huge investment, along with resulting superfluous costs of failure, at times, exceeding even the entire cost of the software per se. Thus, as evident from the extant literature, the issue of achieving success in an ERP implementation initiative has attracted multiple researchers over the past few decade. To further compound the issue, the review of literature additionally indicates that even the definition of success of implementation of ERP, does not share a common understanding amongst the researchers and many of the companies have assumed merely completing the process of implementation of ERP within budget as a measure of success. This basis of defining success completely overlooks the ultimate objectives of ERP implementation delivering expected benefits for the business, offering a vehicle for operational effectiveness in the post implementation stage of ERP life cycle. According to (Lucas, Stern, Walton, \& Ginzberg, 1988), the worth of an ERP system, to some extent, is affirmed by the likelihood of transforming the associated investments efficiently into valuable outcomes for the business. This affirmation however, can generally be done in the ERP post implementation stage, for it is in this period alone, that the ERP system is being put to use by the organization for executing its business process processes and the associated tasks.

(Bingi, Sharma, \& Godla, 1999) noted that a few organisation having adopted ERP solution, have not been able to realize the business benefits expected from the system. The reason for this situation, as per (Ehie \& Madsen, 2005; Jasperson, Carter, \& Zmud, 2005; Lorenzo, 2001), is that the such organizations have not been able to appropriately make use the implemented system to enable them reap expected benefits. (Barker \& Frolick, 2003; Scott \& Vessey, 2002) argue that one of the prominent reasons for ERP failure in an organization, is the unwillingness of its staff to use the recently implemented ERP system. (Venkatesh, Brown, Maruping, \& Bala, 2008) report that one of the reasons for a company not been able to claim the benefits of an information system is the level of utilization of the newly implemented information system being much below the expected one. All these issues point to the post implementation phase of ERP or Information 
system life cycle. (Davis, Bagozzi, \& Warshaw, 1989) report a technology acceptance model maintaining that acceptance of the users play a key role in achieving success in implementation.

(Pozzebon, 2000) suggest that the utility of ERP system is asserted by the employees of the organization using it. More the is the usage of ERP system by the employees of the organization, better is the value it delivers to the organization in terms of the organization being able to achieve expected benefits. (Deng, Doll, \& Truong, 2004) vide their paper report that driving ERP users to use the system effectively is an important issue, an organization has to deal with. While the decision to adopt an ERP solution rests with the organization, system's effectiveness determined by its usage and associated efforts required, depend on the employees.

(Deng, 2000) reports that after the implementation of an information system, post implementation phase, is a continuous learning phase. (Doll, Deng, \& Scazzero, 2003) state that continuous improvement in using information technology systems is a part of its post implementation learning and impact user's work. Any impediment in the process of continuous learning therefore, will lead to a mismatch between usage of IT and reaping associated expected benefits. Thus effective use of the IT systems is determined by the continuous learning during the post implementation phase, on the part of the users, which in turn leads to a larger influence on the work. (Cooper \& Zmud, 1990) report that for an organization to claim full potential of its IT systems, continuous post implementation learning is an important consideration.

From the model of success proposed by (DeLone \& McLean, 2003), we draw that usage of an information systems by its users form an important part of key ingredients delivering success. Usage measurement as suggested by (Burton-Jones \& Straub, 2006), must three aspects namely, one - the user using the information systems, two - the task or the function being performed by the user using the information system being considered, and three - the information system per se. The behaviour of the user associated with the performance being exhibited, in reality depicts the way an information system is being used in organizations is what is proposed by (Melone, 1990). The performance of users at the individual level, as shown by (Kositanurit, Ngwenyama, \& OseiBryson, 2006), is significantly influenced by their usage of information systems. As suggested by (Doll \& Torkzadeh, 1998), the information technology systems at work place are used by individual users for variety of functions including solving various problems, horizontal and vertical communications binding the organizations, connecting with the customers, suppliers, vendors and partners to deliver associated expectations. As noted by (Lin, Hsu, \& Ting, 2006), usage of ERP systems definitely influence the working of individual users at work place. This shows the multifaceted view of information system usage along with establishing an important purpose of an information technology system in its post implementation era. The usage of information system in the post implementation stage boosts task performance at work, has been suggested by (Cooper \& Zmud, 1990). From the above observations it follows that post implementation phase and the productivity, the performance of individual user's therein, play a critical role in organizations reaping business benefits out of an Information system solution in general and an ERP system in particular, getting implemented. This study proposes to examine the influence of a two factors, namely the Gender and the period of ERP operations after its implementation, liable to be impacting an important consideration and construct associated with the ERP system in the post implementation phase - the user productivity. 


\section{Materials and Methods}

The study examined the influence of "Gender" and "Period of ERP post implementation operations in years" on "User Productivity" during ERP post-implementation stage. Following construct was used for the study:

Sample Size: 101

Sample Design: Purposive

Research Design: Factorial Design of ANOVA and Descriptive Analysis

Data Collection Method: Survey - Primary Data collected using a Questionnaire

Hypotheses: Following hypotheses were formulated for the study.

H0: There is no significant difference in the average ratings for improvement in user productivity during ERP post-implementation stage, across Gender.

H1: There is a significant difference in the average ratings for improvement in user productivity during ERP post-implementation stage, across Gender.

H0: There is no significant difference in the average ratings for improvement in user productivity during ERP post-implementation stage across Period of ERP post implementation operations in years.

H1: There is a significant difference in the average ratings for improvement in user productivity during ERP post-implementation stage across Period of ERP post implementation operations in years.

H0: There is no significant effect of the combination of Gender and Period of ERP post implementation operations in years, on the average ratings for improvement in user productivity during ERP post-implementation stage.

H1: There is a significant effect of the combination of Gender and Period of ERP post implementation operations in years, on the average ratings for improvement in user productivity during ERP postimplementation stage.

Tool: A factorial design of ANOVA and Descriptive analysis was used for the above objective.

\section{Results and Discussions}

Following tables illustrate the outcome of the analysis conducted on the primary data using the tool:

Table 3.1: Category-wise spread of respondents across demographic factors

\begin{tabular}{|c|c|c|}
\hline \multicolumn{3}{|l|}{ Between-Subjects Factors } \\
\hline Demographic Factors & Categories & $\mathbf{N}$ \\
\hline \multirow{3}{*}{ Period of ERP post implementation operations in years } & Less than 1 year & 31 \\
\hline & $1-5$ years & 50 \\
\hline & Above 6 years & 20 \\
\hline \multirow[t]{2}{*}{ Gender } & Male & 56 \\
\hline & Female & 45 \\
\hline
\end{tabular}


The data in the table 3.1 above shows group wise survey responses received across demographic factors. The mix show a balanced representation of all the groups across both the demographic factors, and can be considered appropriate to support cause of the study.

Table 3.2: Output of ANOVA (Factorial Design - Tests of Between-Subjects Effects)

\begin{tabular}{|l|c|c|c|c|c|}
\hline Dependent Variable: Improvement in the productivity of users, post ERP implementation. \\
\hline Source & $\begin{array}{c}\text { Type III Sum of } \\
\text { Squares }\end{array}$ & Df & $\begin{array}{c}\text { Mean } \\
\text { Square }\end{array}$ & F & Sig. \\
\hline Model & $1228.117^{\mathrm{a}}$ & 6 & 204.686 & 423.802 & .000 \\
\hline $\begin{array}{l}\text { Period of ERP post implementation } \\
\text { operation in years }\end{array}$ & 40.139 & 2 & 20.069 & 41.554 & .000 \\
\hline Gender & 25.190 & 1 & 25.190 & 52.155 & .000 \\
\hline $\begin{array}{l}\text { Period of ERP post implementation } \\
\text { operation in years * Gender }\end{array}$ & 4.484 & 2 & 2.242 & 4.642 & .012 \\
\hline Error & 45.883 & 95 & .483 & & \\
\hline Total & 1274.000 & 101 & & & \\
\hline a. R Squared = .964 (Adjusted R Squared $=.962)$ & & & & \\
\hline
\end{tabular}

From the Table 3.2 above, it is seen that the $p$ value for demographic factor:

- Gender is less than .05 (Significance level). The null hypothesis is therefore, not accepted. It therefore follows that the average ratings for the Improvement in user productivity during ERP post implementation stage, are not equal across demographic factor Gender. Thus, it can be concluded that the demographic factors Gender has a significant influence on the ratings for Improvement in user productivity during ERP post implementation stage.

- Period of ERP post-implementation operations, is less than .05. The null hypothesis is therefore, not accepted. It therefore follows that the average ratings for the Improvement in user productivity during ERP post implementation stage, are not equal across demographic factor Period of ERP post implementation operation. Thus, it can be concluded that the demographic factor Period of ERP post implementation operation, has a significant influence on the ratings for Improvement in user productivity during ERP post implementation stage.

- Gender and Period of ERP post-implementation operations, taken together, is less than .05. The null hypothesis is therefore, not accepted. It therefore follows that the average ratings for the Improvement in user productivity during ERP post implementation stage, are not equal across demographic factors Gender and Period of ERP post implementation operation, taken together. Thus, it can be concluded that the demographic factors Gender and Period of ERP post implementation operation, taken together, have a significant influence on the ratings for Improvement in user productivity during ERP post implementation stage.

- To further, to understand and explain differences observed between the groups across demographic factors, a descriptive analysis was undertaken. The output for the descriptive analysis showing influence of Independent variables Gender, Period of ERP post implementation operation and their combination considered together, on dependent variable Improvement in the productivity of users post ERP implementation, is recorded in the tables 3.3, 3.4, 3.5, below: 
Table Error! No text of specified style in document.. 1 - Estimated mean ratings for influence of Gender on Improvement in productivity of users post ERP implementation

\begin{tabular}{|l|c|c|c|c|}
\hline \multicolumn{5}{|c|}{ Independent Variable: Gender } \\
\hline Dependent Variable: Improvement in the productivity of users, post ERP implementation \\
\hline \multirow{2}{*}{ Gender } & Mean & Std. Error & \multicolumn{2}{|c|}{ 95\% Confidence Interval } \\
\cline { 3 - 5 } & & & Lower Bound & Upper Bound \\
\hline Male & 2.972 & .096 & 2.781 & 3.163 \\
\hline Female & 4.072 & .118 & 3.838 & 4.306 \\
\hline
\end{tabular}

From the data in the Table 3.3 above, it can be seen that the Female users have recorded a higher mean rating as compared to the Male users. This may be explained by looking at probable variation in the level of commitment and dedication of the female employees, in comparison to their male counterparts. Female employees generally being seen extra dedicated, are expected to exhibit better productivity and hence higher mean rating given by them.

Table 3.4: Estimated mean ratings for influence of Period of ERP post implementation operations in years on Improvement in productivity of users post ERP implementation

\begin{tabular}{|l|c|c|c|c|}
\hline \multicolumn{4}{|c|}{ Independent Variable: Period of ERP post implementation operations in years } \\
\hline Dependent Variable: Improvement in the productivity of users, post ERP implementation \\
\hline $\begin{array}{l}\text { Period of ERP post implementation operations in Mean } \\
\text { years }\end{array}$ & $\begin{array}{c}\text { Std. } \\
\text { Error }\end{array}$ & \begin{tabular}{c}
$\mathbf{9 5 \%}$ Confidence Interval \\
\cline { 3 - 5 }
\end{tabular} & $\begin{array}{c}\text { Lower } \\
\text { Bound }\end{array}$ & $\begin{array}{c}\text { Upper } \\
\text { Bound }\end{array}$ \\
\hline Less than 1 year & 2.592 & .126 & 2.341 & 2.843 \\
\hline 1-5 years & 3.540 & .098 & 3.345 & 3.735 \\
\hline 6 years and above & 4.434 & .163 & 4.111 & 4.757 \\
\hline
\end{tabular}

A look at the data in the Table 3.4 above, shows that the users in the higher brackets of Period of ERP post implementation operations, have shown higher mean rating for improvement in the productivity in comparison to those in the lower brackets. The observation may be accounted for by considering the variation in the number of improvements incorporated in the ERP system over a period of time, being more for higher period and also the extent of exposure of users to the functionalities and working of ERP system, being more for users from higher operation period. The users from higher Period of ERP post implementation operations, therefore, show higher mean ratings for improvement in their productivity as compared to the ones from lower period brackets.

Table 3.5: Estimated mean ratings for influence of Gender and Period of ERP post implementation operations in years, taken together, on Improvement in productivity of users post

\begin{tabular}{|c|c|c|c|c|c|}
\hline \multicolumn{6}{|c|}{ Independent Variable: Gender * Period of ERP post implementation operations in years } \\
\hline \multicolumn{6}{|c|}{ Dependent Variable: Improvement in the productivity of users, post ERP implementation } \\
\hline \multirow{2}{*}{\multicolumn{2}{|c|}{$\begin{array}{c}\text { Gender|Period of ERP post implementation } \\
\text { operations in years }\end{array}$}} & \multirow[t]{2}{*}{ Mean } & \multirow[t]{2}{*}{$\begin{array}{l}\text { Std. } \\
\text { Error }\end{array}$} & \multicolumn{2}{|c|}{$\begin{array}{l}\text { 95\% Confidence } \\
\text { Interval }\end{array}$} \\
\hline & & & & $\begin{array}{l}\text { Lower } \\
\text { Bound }\end{array}$ & $\begin{array}{l}\text { Upper } \\
\text { Bound }\end{array}$ \\
\hline \multirow[t]{2}{*}{ Male } & Less than 1 year & 1.722 & .164 & 1.397 & 2.047 \\
\hline & $1-5$ years & 3.040 & .139 & 2.764 & 3.316 \\
\hline
\end{tabular}




\begin{tabular}{|l|l|c|c|c|c|}
\hline & 6 years and above & 4.154 & .193 & 3.771 & 4.537 \\
\hline \multirow{3}{*}{ Female } & Less than 1 year & 3.462 & .193 & 3.079 & 3.844 \\
\cline { 2 - 6 } & $1-5$ years & 4.040 & .139 & 3.764 & 4.316 \\
\cline { 2 - 6 } & 6 years and above & 4.714 & .263 & 4.193 & 5.236 \\
\hline
\end{tabular}

\section{ERP Implementation}

From the data in the table 3.5 above, it is clear that the influence of combination of Gender and Period of ERP post implementation operations in years, taken together, on the Improvement in the productivity of users post ERP implementation exhibit trends similar to the ones observed in the case on influence of individual factors. This may be understood on the lines similar to the one considered for explaining the variation in the influence of individual factors.

\section{Conclusions and Recommendations}

The outcomes and findings from the results of the A factorial design of ANOVA illustrated earlier in section 3 -Results and discussions, clearly reveals that the null hypotheses is not accepted. It may thus be drawn that the two factors "Gender" and "Period of ERP post implementation operations in years", being examined, significantly influence the "Improvement in the productivity of users, post ERP implementation". The descriptive study further explained that the trends in the variation being observed in case of individual demographic factors influencing "Improvement in the productivity of users, post ERP implementation" and showed that the trends in the variations observed in case of both the demographic factors considered together are also similar to the ones noted in case of demographic factors considered individually.

The findings of the study besides contributing to the body of knowledge, may be useful for effectively managing ERP post implementation operations. This may therefore be of interest to the stakeholders, including the Administrators, senior management, Program management groups, ERP consultants and ERP solution providers, involved in monitoring and driving ERP post implementation operations, especially, in HEI settings, in Indian context.

ERP Post implementation stage in an HEI setting, in an emerging economy like India, being a less explored area, the results of this study motivate the researcher to recommend considering similar study with other demographic factor including age, job role, and work experience and likes.

\section{References}

[1] Barker, T., \& Frolick, M. N. (2003). ERP implementation failure: A case study. Information Systems Management. https://doi.org/10.1201/1078/43647.20.4.20030901/77292.7

[2] Bingi, P., Sharma, M. K., \& Godla, J. K. (1999). Critical issues affecting an ERP implementation. Information Systems Management. https://doi.org/10.1201/1078/43197.16.3.19990601/31310.2

[3] Burton-Jones, A., \& Straub, D. W. (2006). Reconceptualizing system usage: An approach and empirical test. Information Systems Research. https://doi.org/10.1287/isre.1060.0096

[4] Cooper, R. B., \& Zmud, R. W. (1990). Information Technology Implementation Research: A Technological Diffusion Approach. Management Science. https://doi.org/10.1287/mnsc.36.2.123

[5] Davis, F. D., Bagozzi, R. P., \& Warshaw, P. R. (1989). User Acceptance of Computer Technology: A Comparison of Two Theoretical Models. Management Science. https://doi.org/10.1287/mnsc.35.8.982 
[6] DeLone, W. H., \& McLean, E. R. (2003). The DeLone and McLean model of information systems success: A ten-year update. Journal of Management Information Systems. https://doi.org/10.1080/07421222.2003.11045748

[7] Deng, X. (2000). Developing an information technology learning model in a computer -integrated manufacturing (CIM) context.

[8] Deng, X., Doll, W. J., \& Truong, D. (2004). Computer self-efficacy in an ongoing use context. Behaviour and Information Technology. https://doi.org/10.1080/01449290410001723454

[9] Doll, W. J., Deng, X., \& Scazzero, J. A. (2003). A process for post-implementation IT benchmarking. Information and Management. https://doi.org/10.1016/S0378-7206(03)00048-X

[10] Doll, W. J., \& Torkzadeh, G. (1998). Developing a multidimensional measure of system-use in an organizational context. Information and Management. https://doi.org/10.1016/S03787206(98)00028-7

[11] Ehie, I. C., \& Madsen, M. (2005). Identifying critical issues in enterprise resource planning (ERP) implementation. Computers in Industry. https://doi.org/10.1016/j.compind.2005.02.006

[12] Jasperson, J., Carter, P. E., \& Zmud, R. W. (2005). A comprehensive conceptualization of postadoptive behaviors associated with information technology enabled work systems. MIS Quarterly: Management Information Systems. https://doi.org/10.2307/25148694

[13] Kositanurit, B., Ngwenyama, O., \& Osei-Bryson, K. M. (2006). An exploration of factors that impact individual performance in an ERP environment: An analysis using multiple analytical techniques. European Journal of Information Systems. https://doi.org/10.1057/palgrave.ejis.3000654

[14] Lin, H. Y., Hsu, P. Y., \& Ting, P. H. (2006). ERP systems success: An integration of IS success model and balanced scorecard. Journal of Research and Practice in Information Technology.

[15] Lorenzo, O. (2001). Human, contextual, and processual issues influencing enterprise system use. AMCIS 2001 Proceedings.

[16] Lucas, H. C., Stern, L. N., Walton, E. J., \& Ginzberg, M. J. (1988). Implementing packaged software. MIS Quarterly: Management Information Systems. https://doi.org/10.2307/249129

[17] Melone, N. P. (1990). A Theoretical Assessment of the User-Satisfaction Construct in Information Systems Research. Management Science. https://doi.org/10.1287/mnsc.36.1.76

[18] Pozzebon, M. (2000). Combining a Structuration Approach with a Behavioral-Based Model to Investigate ERP Usage. AMCIS 2000 Proceedings.

[19] Scott, J. E., \& Vessey, I. (2002). Managing Risks in Enterprise Systems Implementations. Communications of the ACM. https://doi.org/10.1145/505248.505249

[20] Venkatesh, V., Brown, S. A., Maruping, L. M., \& Bala, H. (2008). Predicting different conceptualizations of system USE: The competing roles of behavioral intention, facilitating conditions, and behavioral expectation. MIS Quarterly: Management Information Systems. https://doi.org/10.2307/25148853

\footnotetext{
*Corresponding author.

E-mail address: nirmal_i@yahoo.com
} 